\title{
Guiding Reflective Practice: An Auditing Framework to Assess Teaching Philosophy and Style
}

Journal of Marketing Education

32(2) 182-196

(C) 2010 SAGE Publications

Reprints and permission: sagepub.com/journalsPermissions.nav DOI: | 0.1 I 77/027347530936016 | http://jmd.sagepub.com (SAGE

\author{
Philip A.Titus' and Dwayne D. Gremler'
}

\begin{abstract}
Growing as an educator takes hard work and commitment. It requires the educator to engage in regular, objective selfexaminations of instructional beliefs and behaviors. Although this task can be daunting, and unwieldy, due to the complexity of the teaching-learning exchange, it can also be undertaken in a systematic manner. This article proposes a framework of five elements that appear essential for assessing instructor beliefs and behaviors: content, learner, educator, social setting, and physical environment where the instruction takes place. A teaching-style audit is demonstrated to show how the systematic and thoughtful assessment of an educator's teaching philosophy and style can be undertaken. This research contributes to the professional development of marketing educators by (a) providing a unifying framework to guide reflective teaching practice and (b) proposing that an auditing approach should be used to reveal incomplete or underdeveloped areas of instructional belief and identify inconsistent or incongruent teaching styles.
\end{abstract}

\section{Keywords}

reflective, teaching, philosophy, style, assessment

Teaching is a complex, fluid activity that can be difficult to describe or define. Conceptually, it consists of an activity that transfers knowledge from instructor to student in a teaching-learning exchange process. This exchange requires the educator to make multiple instructional judgments, devise effective learning activities, and decide how best to design the student learning experience. Over time, the consistent pattern of instructional choices made by each educator produces a unique instructional approach or style. Marketing educators recognize the importance of understanding how various teaching methodologies and styles influence student learning (Henke, Locander, Mentzer, \& Nastas, 1988; Roach, Johnston, \& Hair, 1993). An educator's instructional approach may result from a systematic, thoughtful effort that reflects his or her personal educational philosophy, though it also is not uncommon for educators to develop an instructional style without much conscious reflection, relying heavily on the teaching style modeled by their mentors or past admired teachers (Heimlich \& Norland, 2002; Robinson, Ross, \& White, 1985).

Conscientious pedagogical reflection is necessary to produce a complete, well-developed teaching philosophy. The absence of pedagogical reflection can result in daily instruction that fails to reflect an instructor's teaching philosophy or instructional belief system accurately. In particular, an underdeveloped teaching philosophy may translate into a teaching style full of inconsistencies, characterized by poorly coordinated and designed instruction (Heimlich \& Norland, 2002). For example, a poorly developed set of beliefs about what constitutes strong marketing content may result in the mindless reliance on topical coverage included in an assigned text. Likewise, valuable marketing content may be excluded inadvertently without well-developed criteria for content selection. Similarly, if little thought has been devoted to the desired level of content mastery, the instructional activities may focus primarily on knowledge acquisition, excluding higher-order learning such as content application, synthesis, or evaluation. Finally, the absence of well-developed instructional beliefs about how students learn leaves little opportunity to provide marketing instruction that accounts for individual differences in learning styles. These few examples illustrate how instructional inconsistencies may surface in teaching styles. They also highlight that it would behoove marketing educators to examine their teaching philosophy and style

'Bowling Green State University, Bowling Green, OH, USA

Corresponding Author:

Philip A.Titus, Department of Marketing, College of Business

Administration, Bowling Green State University, Bowling Green, $\mathrm{OH}$

43403, USA

Email: ptitus@bgsu.edu 
periodically, with an eye toward advancing their instructional effectiveness.

A fundamental goal for every educator should be to grow continually as a teaching professional. Such instructional growth requires hard work and commitment. Specifically, serious growth requires an educator to engage regularly in an objective self-examination of his or her instructional beliefs and behaviors. This reflective process should proceed in a thoughtful, systematic fashion. Unfortunately, the complexity and time-consuming nature of teaching leaves many educators with little time to reflect on their underlying instructional beliefs, or they do so in a rather haphazard manner. The purpose of this article is to (a) promote the professional development of marketing educators by providing a theoretical framework to guide reflective teaching practices and (b) extend our understanding of teaching styles by suggesting an auditing approach to use to identify instructional inconsistencies that exist between teaching philosophies and behaviors. To that end, we suggest that a teaching-style audit may help marketing educators systematically examine their teaching philosophy and style, and we present an audit instrument to illustrate how this approach might be implemented.

\section{Literature Review}

\section{Teaching Style Research}

Prior research defines the concept of teaching style in various ways. Fisher and Fisher (1979) conceptualize it as a pervasive quality within the behavior of an educator that persists, even though the content may change. Cross (1979) uses the concept of style to describe the manner in which a teacher transforms information into useful knowledge. Other researchers, such as Conti $(1985,1990)$ and Oliva (1982), view teaching style as a unique set of personal characteristics, traits, and qualities displayed by individual instructors that clearly identifies them as unique teachers. As Heimlich and Norland (2002, p. 17) note, most researchers conceptualize teaching style "as a predilection toward teaching behavior and the congruence between an educator's teaching behavior and teaching beliefs." According to this view, teaching style takes on a broad definition and reflects more than just the consistent use of teaching methods. Rather, it refers to consistency of teaching behavior, driven by the relationship between instructional beliefs and behavior. Thus, to appreciate a person's teaching style, it is necessary to investigate not only the particular instructor behaviors that enhance student learning but also the underlying teaching philosophy or belief system that directs those behaviors.

Most empirical work on teaching styles focuses on identifying and classifying teachers according to their pattern of teaching behavior (Axelrod, 1970; Fisher \& Fisher, 1979;
Henke et al., 1988; Leung, Lue, \& Lee, 2003; Mann, 1970; Roach et al., 1993; Saroyan \& Snell, 1997). This classification focus appears driven, at least in part, by a desire to identify a common set of teaching behaviors that embody the "optimal" teaching style. Roach et al. (1993) identify three predominant teaching styles, based on the pattern of studentfaculty interaction that results from the mix of instructional methods employed by the instructor (i.e., lecture, class discussion, computer simulations, presentations, projects, business interaction). These three teaching styles are (a) a lecture-dominant teaching style, referred to as "student passive;" (b) a teaching style characterized by heavy two-way communication between student and faculty, labeled "student communication;" and (c) a "student interaction" teaching style dominated by heavy student involvement in practical, hands-on learning activities.

Other researchers identify the patterns of verbal educator behaviors (e.g., assertive, suggestive, collaborative, facilitative) that occur during teacher-student interactions (Leung et al., 2003). In their investigation of variations in lecturing styles, Saroyan and Snell (1997) identify three styles characterized by different instructional foci: content driven, context driven, and pedagogy driven. Oliva (1982) suggests that teachers consciously or unconsciously adopt certain roles that can differentiate their teaching styles. For example, these roles may include the teacher as entertainer, priest, expert, disciplinarian, or socializing agent (e.g., Adelson, 1961; Axelrod, 1973; Heck \& Williams, 1984; Mann, 1970). This stream of research, though useful, primarily provides descriptive accounts of teaching style. Noticeably absent is research that offers techniques for assessing an educator's instructional style.

\section{The Marketing Audit Concept}

Employing an audit-style framework to assess performance has been widely accepted and advocated by marketing researchers (Berry, Conant, \& Parasuraman, 1991; Kotler, Gregor, \& Rogers, 1977; Shuchman, 1959). For example, marketing audits offer a periodic assessment technique designed to improve marketing operations within the firm (Berry et al., 1991). The basic audit concept thus provides an excellent framework for assessing teaching philosophy and style. Conceptualized as a systematic, critical review of a firm's marketing assumptions and activities (Mokwa, 1986; Shuchman, 1959), marketing audits generally consist of a series of open-ended questions, presented in a checklist. These questions attempt to identify operational weaknesses in the organization's marketing activities and performance. Beyond their obvious strategic benefits, marketing audits also can help firms develop stronger marketing orientations or philosophies (Payne, 1988).

Marketing scholars have acknowledged the flexibility of the audit approach and its possible application to other 
important areas of marketing performance (Berry et al., 1991; Mokwa, 1986). The teaching domain provides a fruitful context for such an extended application, for several reasons. First, the checklist format of an audit facilitates systematic evaluations of the complex activity of teaching. Second, a teaching audit can identify weaknesses in teaching performance that may result from underdeveloped instructional beliefs and/or discrepancies in teaching styles. Third, a teaching audit might facilitate reflective teaching practices by providing directions for marketing educators as they systematically ponder their fundamental instructional beliefs and behaviors.

\section{Reflective Teaching and Style Congruence}

Reflective teaching repeatedly has been identified and advocated as a meaningful and expected instructional practice (Hall, 1997; Osterman, 1990; Osterman \& Kottkamp, 1993; Ramsden, 1992; Schon, 1983, 1987). According to Hall (1997, p. 125), reflective teaching "is essentially teaching practice in which the teacher undertakes deliberate and sustained reflection and action for the purpose of (instructional) improvement." Most educators consider reflective teaching to be an expected competency for all teaching professionals (Ramsden, 1992) that requires the ability to articulate one's own knowledge, assumptions, and beliefs regarding the practice of teaching (Osterman, 1990; Osterman \& Kottkamp, 1993). When educators clarify their teaching beliefs and philosophy, the contradictions or discrepancies between what they believe and what they do become readily apparent (Osterman \& Kottkamp, 1993; Schon, 1983). Osterman and Kottkamp (1993, p. 8) argue that "the decisions we make, [and] the actions we take," as educators, depend on our personal theories of instruction. These instructional theories reflect the conscious beliefs we possess about what we, as educators, consider effective teaching practice. Personal theories of instruction can guide teaching behavior, but they also might diverge, which gives rise to potential discrepancies or inconsistencies that hinder teaching effectiveness (Osterman \& Kottkamp, 1993).

Like other fields of instruction, marketing education is not exempt from teaching practices (i.e., teaching styles) that contain inconsistent or incongruent behavior. Some observers might even argue that limited pedagogical training and background has made the problem of teaching style incongruence especially prevalent among marketing educators. Most instructional inconsistencies surface because educators (a) neglect or fail to make reflective teaching an integral part of their instructional practice or (b) possess incomplete, underdeveloped instructional beliefs or teaching philosophies that foster incongruent teaching styles and result in poorly designed and coordinated marketing instruction. Such instructional inconsistencies must be identified and minimized if educators are to develop a cohesive, congruent teaching style that delivers effective marketing instruction. In particular, a congruent teaching style reflects instruction that is theory driven and for which the planned learning activities support the stated learning objectives. Educators who possess incongruent teaching styles risk failing to "practice what they preach," espousing one educational theory but acting in a manner inconsistent with that belief. In summary, an incongruent teaching style reflects marketing instruction that lacks pedagogical thought and purpose, which makes it difficult to effectively design and coordinate instructional activities.

Reflective teaching practice entails a type of "self-research," designed to provide greater awareness of a person's own instructional beliefs and practices (Humphreys \& Ziva, 2000; Osterman \& Kottkamp, 1993). Several existing reflective teaching practices, as presented in Table 1, can facilitate personal reflection and self-discovery (e.g., Osterman \& Kottkamp, 1993) through activities such as educator interviews, peer teaching observations, teaching journals or case records, videotaping, role playing, or the use of personal inventories. Although beneficial, these reflective teaching practices stop short of providing pedagogical frameworks to guide their implementation. This article represents an initial attempt to fill this void by providing a unifying pedagogical framework to guide reflective marketing instruction.

\section{The Marketing Teaching-Learning Exchange}

The complexities and intricacies associated with teaching suggest that the number of instructional issues to contemplate is almost limitless, making the thought of conscientious pedagogical reflection seem overwhelming to many marketing educators. To simplify the process of personal reflection, educators might employ a theoretical framework that enables them to organize and reflect on important instructional issues. We propose and discuss a pedagogical model of the marketing teaching-learning exchange that flows from the findings of previous instruction-related research (Heimlich \& Norland, 2002; Richey, 1986).

Marketing instruction, as conceptualized herein, involves the process of exchanging ideas, attitudes, and knowledge between an educator and his or her student(s). The nature and effectiveness of each instructional activity depends largely on the set of temporal or situational forces present during the teaching-learning exchange process (Heimlich \& Norland, 2002). Heimlich and Norland (2002) contend that every educational event contains five basic elements: the teacher, learner, group, content, and (learning) environment. Furthermore, Heimlich and Norland argue that the relationship among these elements depends on the situation and how "the educator operationalizes personal beliefs regarding the relationship and importance of each component" (p. 17). 
Table I. Reflective Teaching Practices

\begin{tabular}{|c|c|}
\hline \multicolumn{2}{|r|}{ Description } \\
\hline \multicolumn{2}{|c|}{ I. Assessing teaching philosophy } \\
\hline Personal interviews & Open-ended questioning of educators by trusted colleagues or administrators. \\
\hline Written statements & Educator prepared written statements of teaching philosophy. \\
\hline Case studies & $\begin{array}{l}\text { Analytic technique designed to capture teaching beliefs and values. Educator is presented with a } \\
\text { hypothetical teaching (case) problem to resolve. Case responses are later examined to reveal specific } \\
\text { teaching beliefs underlying the educator's teaching responses. }\end{array}$ \\
\hline \multicolumn{2}{|c|}{ II. Assessing teaching behavior } \\
\hline \multicolumn{2}{|c|}{ Direct observations } \\
\hline Shadowing & $\begin{array}{l}\text { Third-party observations. Experienced, knowledgeable, colleague observes teaching practices and provides } \\
\text { feedback regarding instructional behavior. Followed by educator evaluation and reflection. }\end{array}$ \\
\hline Videotaping & Educator evaluation and reflection of personal videotaped teaching practices. \\
\hline Role plays & $\begin{array}{l}\text { Simulated teaching practice. Educator simulates instructional response to hypothetical teaching situation. } \\
\text { Followed by educator educator evaluation and reflection. }\end{array}$ \\
\hline \multicolumn{2}{|l|}{ Written narratives } \\
\hline Teaching journals & $\begin{array}{l}\text { Daily written accounts of daily teaching practices, thoughts, problems, events. Followed by educator } \\
\text { evaluation and reflection. }\end{array}$ \\
\hline Case records & $\begin{array}{l}\text { Structured written account of specific teaching experiences, complete with responses to standard } \\
\text { prompts. For example,"What did you hope to accomplish? Were your actions effective? Why? Why not?" } \\
\text { Followed by educator self-evaluation and reflection. }\end{array}$ \\
\hline Content analysis & $\begin{array}{l}\text { Educator analysis of personal teaching materials (e.g., syllabus, lecture notes, PowerPoint slides, exams, } \\
\text { student assignments). Followed by educator self-evaluation and reflection. }\end{array}$ \\
\hline Personal inventories & Instruments designed to capture teaching attitudes, perceptions, or other aspects of teaching behavior. \\
\hline Teaching-style audit & $\begin{array}{l}\text { Reflective teaching practice guided by established pedagogical prompts and questions that address specific } \\
\text { teaching beliefs and behaviors. }\end{array}$ \\
\hline
\end{tabular}

In related research, Richey (1986) features a similar set of instructional variables in her conceptual model of instructional design, which is based on four clusters of instructional variables that directly affect student learning and achievement. Richey found student achievement to be a function of the characteristics of the learner, the precise content of the material delivered, the characteristics of the learning environment (both social and physical), and the delivery or method of instruction.

Both Richey's (1986) and Heimlich and Norland's (2002) models include pedagogical elements that appear strikingly similar and thus serve as the foundation on which we base our proposed teaching-learning exchange model (Figure 1). In accordance with prior research, we posit that educators possess a set of teaching beliefs pertinent to each of five pedagogical elements that influence each teaching event. These pedagogical elements refer to the content (marketing), the learner (student), the (marketing) educator, the social setting (group), and the physical learning environment in which marketing instruction occurs.

In accordance with the proposed framework, we contend that an educator's instructional beliefs about the importance and role of each pedagogical element constitute his or her teaching philosophy. Furthermore, educators develop, select, and implement instructional activities according to their beliefs about how each element influences their teaching effectiveness. The manner in which an educator uses and responds to each pedagogical element largely defines his or her teaching style. We examine the relationships among an educator's teaching philosophy, style, and individual elements of the marketing teaching-learning exchange next.

\section{The Marketing Content}

Content selection reflects a key instructional design decision (Armstrong, 1989; Freiberg \& Driscoll, 2000; Richey, 1986; Wiles \& Bondi, 2002) and plays a significant role in determining teaching style (Freiberg \& Driscoll, 2000; Heimlich \& Norland, 2002; Oliva, 2005), because it requires difficult decisions about what constitutes good marketing content. For example, marketing educators must determine the appropriate type (e.g., theoretical, applied, skill-based), amount, difficulty, and mix of marketing content to achieve the desired level of content mastery (e.g., basic comprehension, application, synthesis). Marketing educators also must consider other content-related instructional decisions, such as the role and type of marketing support materials to use (e.g., textbooks, readings, software). These decisions generally reflect underlying beliefs or teaching philosophies regarding what constitutes valuable (marketing) content, and they require explicit or implicit criteria on which to judge the value of various content possibilities (Freiberg \& Driscoll, 2000). 


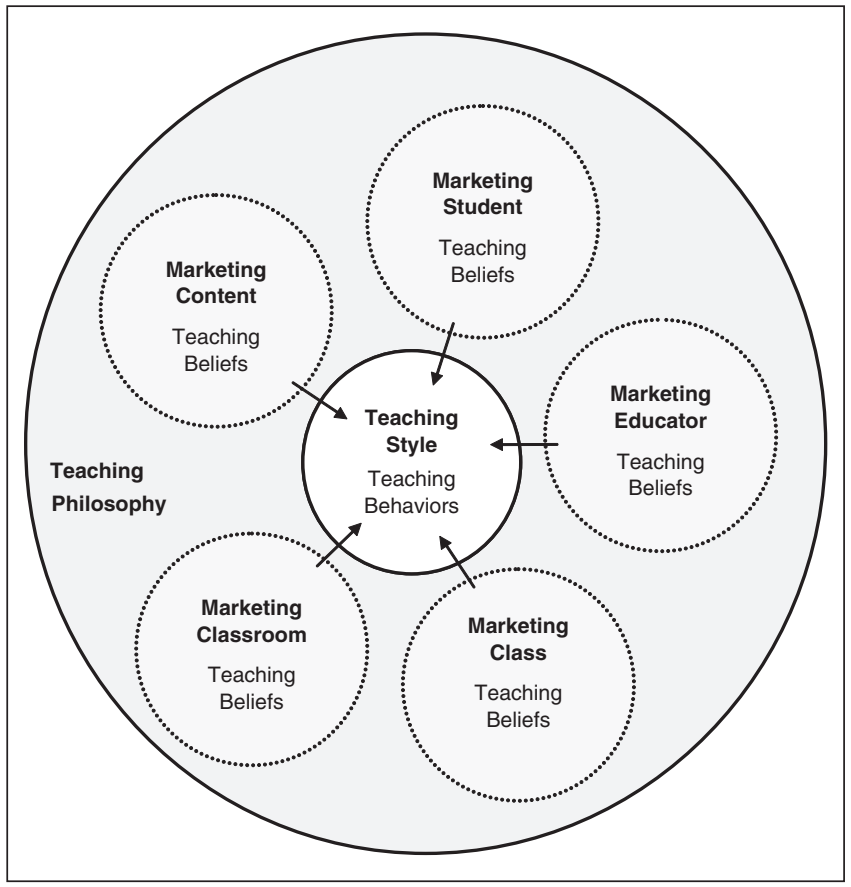

Figure I. Elements of the marketing teaching-learning exchange

The pattern of instructional content selection ultimately affects instructional behavior and learning activities in the course (e.g., theoretical vs. applied). For example, educators who value application-based marketing content likely assign recent marketing cases (e.g., Harvard Business School cases) or readings from practitioner-oriented publications (e.g., Business Week, Advertising Age). In contrast, marketing educators who believe theoretical marketing content is more valuable may focus on content synthesis and assign readings from more academic-oriented publications (e.g., marketing textbooks, marketing journals). Thus, an educator's beliefs about the content element of the teaching-learning exchange play an important role in determining his or her teaching style. In turn, we believe that an audit of teaching philosophy and style must require marketing educators to give serious reflection to their instructional beliefs about which marketing content should be taught.

\section{The Marketing Student}

Teaching style depends significantly on philosophical beliefs about the role, responsibilities, and intellectual capabilities of students involved in the teaching-learning exchange (Freiberg \& Driscoll, 2000; Heimlich \& Norland, 2002; Oliva, 2005; Wiles \& Bondi, 2002). Beliefs regarding the role that students play in the learning process (e.g., spectator, participant, instructional partner, collaborative learner, peer evaluator), for example, can influence the pattern of instructional experiences presented (e.g., active learning exercises, lecture-based instruction, individual vs. group activities). An educator's beliefs about student intellectual motivations (e.g., intrinsic, extrinsic) and prerequisite knowledge also should influence the type and amount of instructional techniques used.

Teaching style also depends on other important instructional beliefs with regard to students. For example, beliefs about how students learn most effectively (i.e., direct experience, demonstration, discovery, independently), student attitudes toward learning, or student course expectations all significantly affect classroom instruction. The pattern of instructional responses that marketing educators adopt because of their fundamental beliefs about learners also affects their personal teaching styles. Marketing educators who view students as instructional partners thus are more likely to require students to identity, select, and present relevant marketing content during regularly scheduled class time. In contrast, marketing educators who view students as spectators may tend to guard closely the amount, type, and frequency of marketing content delivered by students. In summary, educators' philosophical beliefs about and instructional responses to the role, motivation, and intellectual capabilities of students provide key determinants of teaching styles (Freiberg \& Driscoll, 2000; Oliva, 2005). An audit of teaching philosophy and style should require educators to reflect on their beliefs about the intellectual capabilities and maturity of the student.

\section{The Marketing Educator}

The knowledge, attitudes, and abilities of an educator have significant impact on teaching style (Armstrong, 1989; Freiberg \& Driscoll, 2000; Richey, 1986; Robinson et al., 1985). Marketing educators as a group differ greatly in their domainrelated knowledge, experience, and ability to employ various instructional techniques (e.g., case method, cooperative learning, guest lecturers). As a result, they may vary widely in their preference for specific instructional techniques, as well as their beliefs about what constitutes effective teaching practice. Such educator preferences can limit teachingstyle flexibility by affecting both instructional delivery and the type of student learning activities assigned. For example, an experienced marketing educator may possess the confidence (belief) and ability to deliver marketing content using many different instructional approaches, quickly shifting between instructional methods as needed. In contrast, a relatively inexperienced educator may only be comfortable delivering marketing content in a traditional lecture format and thus display a rather rigid teaching style. Teaching style therefore depends on the marketing educator's experience, beliefs, preferences, and abilities.

Educators play various roles in the teaching-learning exchange (Adelson, 1961; Axelrod, 1973). An educator may play the role of expert, role model, motivator, evaluator, facilitator, or manager, just to name a few. The educator's beliefs regarding his or her role in the exchange thus can 
significantly affect his or her teaching style. For example, educators that view their primary instructional role as that of "the expert" may assume the primary responsibility for delivering course content to students. As a consequence, the resultant teaching style would likely be characterized as student passive rather than student interactive. Beliefs about educational roles also may determine the amount of class time devoted to alternative instructional activities. The patterns of instructional behavior produced by these core educator beliefs partially define one's teaching style. Thus, we believe any audit of teaching philosophy and style should include thoughtful reflection on what the marketing educator believes constitutes effective marketing instruction.

\section{The Marketing Class}

The significance of interpersonal relationships to individuals suggest that teaching styles are likely to depend on the social context that surrounds the teaching-learning exchange (Armstrong, 1989; Heimlich \& Norland, 2002; Oliva, 2005). The type and amount of social interaction that occurs within the classroom plays a key role in determining the overall learning climate or atmosphere during the learning process (Richey, 1986). Marketing educators devise and implement important instructional activities to help manage social interactions and create a specific classroom atmosphere (e.g., fun, friendly, competitive, professional). These activities are driven in part by the educator's philosophical beliefs regarding the instructional value of various types of social interaction (i.e., between students, between faculty and students) and their impact on student learning. Marketing educators might value student interactions among diverse groups of students (e.g., work styles, ethnic backgrounds, motivation levels) and therefore create instructional activities that foster such interactions. They also formulate beliefs about how much studentto-student interaction benefits the teaching-learning exchange and how structured that interaction should be. In turn, educators must consider whether students should be assigned clearly defined group roles (e.g., academician, practitioner, or critic) or if student-defined roles should be more ambiguous.

An educator's beliefs regarding the social setting also produce a pattern of pedagogical choices and behaviors that define his or her teaching style (Freiberg \& Driscoll, 2000). For example, marketing educators who wish to foster a competitive learning climate may form student marketing teams and link student grades to the relative performance of those teams. Likewise, educators seeking to promote a professional learning climate might be inclined to communicate with students in a formal manner. Thus, we contend it is important to assess the teaching beliefs and behaviors of marketing educators in terms of the social component of the teachinglearning exchange when auditing their teaching philosophy and style.

\section{The Marketing Classroom}

The final element of the teaching-learning exchange, the physical environment (i.e., the classroom), also can significantly affect teaching styles (Freiberg \& Driscoll, 2000; McNeil, 1996; Nicholls \& Nicholls, 1978; Oliva, 2005; Richey, 1986). In particular, the physical layout and design of the learning environment may facilitate or restrict the use of certain learning activities. Classrooms with mobile seating arrangements tend to provide more flexibility in both small and large group activities; the size and layout of the rooms also may directly affect students' role expectations, interaction, and ultimately the learning climate (Posner \& Rudnitsky, 2001; Wiles \& Bondi, 2002).

Marketing educator beliefs and philosophies with regard to the impact of various design elements on student learning, interaction, and role expectations may lead instructors to alter the design of the classroom to match their desired instructional style. For example, when mobile seats are available, educators may rearrange the seating into small clusters to facilitate cooperative learning activities. Alternatively, certain design elements may force educators to deviate from their desired course of instruction, which alters their preferred teaching style. For example, an educator might believe group learning activities offer a particularly effective learning experience, but the physical layout of the classroom (e.g., large, tiered lecture classroom) may preclude the use of student groups, which requires the marketing educator to abandon the preferred mode of instruction. In summary, the educator's philosophical beliefs about the appropriate role and influence of the physical environment in the teachinglearning exchange may directly affect his or her teaching style. Thus, an audit of personal teaching philosophy and style should include thoughtful reflection about the impact of the physical environment on effective marketing instruction.

\section{A Teaching-Style Audit}

As we discussed previously, the pattern of teaching behavior displayed by an educator depends largely on his or her teaching philosophy. In particular, teaching styles emanate directly from an educator's beliefs regarding the role that each component of the teaching-learning exchange plays in student learning experiences (Heimlich \& Norland, 2002).

\section{Instrument Design and Development}

The teaching-style audit we provide illustrates how marketing educators might use our suggested framework to develop an audit-style instrument that guides their reflective teaching practice. Our audit instrument consists of a series of openended questions that have been designed to elicit educators' fundamental teaching beliefs and behaviors in the marketing teaching-learning exchange (Figure 1). The goal of our 
teaching-style audit is not to identify the single "best" or "correct" teaching philosophy or style; we believe there are many possible teaching philosophies and styles that lead to effective marketing instruction. Rather, our audit offers a means for marketing educators to regularly assess and reflect on their teaching philosophy and style. One of the overarching goals of such an audit therefore is to help marketing educators identify and eliminate areas of instructional inconsistency. Our proposed audit approach also enables marketing educators to identify and strengthen any incomplete, underdeveloped areas in their instructional beliefs.

Given the complexity of the teaching-learning exchange and the volume of potential curricular issues to consider, it would be futile to attempt to construct a complete and definitive list of the points of reflection. However, textbooks addressing curriculum development suggest a common set of issues to consider when developing and executing strategies of instruction (e.g., Freiberg \& Driscoll, 2000; Oliva, 2005; Wiles \& Bondi, 2002). Therefore, the points of reflection in our teaching-style audit come from our content analysis of several different curriculum development and instruction textbooks (e.g., Armstrong, 1989; Freiberg \& Driscoll, 2000; McNeil, 1996; Nicholls \& Nicholls, 1978; Oliva, 2005; Richey, 1986; Robinson et al., 1985; Wiles \& Bondi, 2002). This content analysis revealed a shared set of 32 basic issues to consider when developing strategies of instruction (Table 2), each of which we classified into the five research-based elements of the teaching-learning exchange (Figure 1). We then reformulated the curricular points of reflection into 32 belief-eliciting questions, explored through 220 underlying reflective prompts.

A person's teaching philosophy and style may vary depending on the course taught and the resources available. For example, one teacher might employ a lecture-based instructional style for large classes but shift to an active-learning teaching style for classes containing fewer students. Therefore, our audit instrument is designed to be administered at the course level.

\section{Teaching-Style Audit Analysis}

According to the theoretical perspective offered by Heimlich and Norland (2002), instructional style reflects the relationship between teaching beliefs and behavior. This relationship serves as the focus of our teaching-style audit. Specifically, our teaching-style audit can be structured to enable educators to reflect on their basic philosophical teaching beliefs and then compare those beliefs with their corresponding instructional behaviors. Instructional strategies and practices that are consistent with the philosophical belief system are considered "congruent" and produce congruent teaching styles, whereas behaviors that are inconsistent with the belief system produce an incongruent style.
On completion of the audit, educators should review all their responses and reflect on (a) areas of philosophical strength and weakness, (b) areas of teaching style congruence and incongruence, and (c) new pedagogical initiatives that might increase teaching style congruence. A teaching-style audit approach gives marketing educators the means to assess and reflect on their teaching independently; however, if desired, an audit can be performed in collaboration with a knowledgeable and trusted colleague. To illustrate how a teaching-style audit might be implemented, a sample portion of our audit has been completed and is presented in Appendix A.

Analyzing teaching philosophy. An educator may find it difficult, if not impossible, to respond to specific belief-eliciting questions in the teaching-style audit. Such difficulties, though normal, may reflect pedagogical areas for which the educator has not yet formulated strongly held teaching beliefs. These areas of underdeveloped instructional beliefs likely develop for several reasons, including the possibility that the educator views a particular issue as unimportant or outside his or her control. Yet marketing educators should seek to identify these areas of incomplete or underdeveloped philosophical beliefs and reflect on their significance and value in the teachinglearning exchange. In some cases, educators may deem it necessary to engage in formal or informal professional development to strengthen their belief systems. For example, a marketing educator might undertake an independent pedagogical self-study, discuss teaching philosophy with other more knowledgeable teaching professionals, or participate in formal faculty development workshops or teacher training.

Other belief-eliciting questions included in a teachingstyle audit will be easier to answer. These instances typically reflect instructional areas in which marketing educators possess relatively well-developed philosophical belief systems. For example, most educators have had plenty of exposure to lecture-style instruction and likely have well-developed teaching beliefs regarding its effectiveness. Nonetheless, marketing educators still need to question these instructional beliefs and question their positive or negative impact on the teaching-learning exchange.

The process of validating teaching beliefs can take many forms. An educator might seek belief validation from prior pedagogical research findings; compare their beliefs with those of a knowledgeable, experienced teaching professional; or simply reflect on previous classroom experiences. A conscientious reflection on personal teaching beliefs, regardless of the method used, should foster professional growth while simultaneously improving overall teaching effectiveness.

Analyzing teaching behavior. As Dewey (1933) observes, people do not learn from experience; they learn from reflecting on their experience. Thus, marketing educators must carefully and diligently reflect on their day-to-day teaching behavior. Much of that reflective activity should involve thoughtful comparisons of teaching beliefs with 
Table 2. Teaching-Style Audit (Exploring Your Teaching Philosophy and Style)

\section{I.The Marketing Content}

Marketing domains:

I.Teaching beliefs about what domains of learning are appropriate for this course? Affective domain: market orientation? empathy? ethics? life-long learning? Cognitive domain: problem-solving? innovative thinking? persuasion? Behavioral domain: internships? role play? marketing software operation?

Marketing concepts:

2. Teaching beliefs about what marketing concepts should be taught in this course? customer behavior? product development? distribution? pricing? promotion? marketing research? professional/career information? academic research? marketing case histories? interdisciplinary content?

3. Teaching beliefs about what marketing concepts should be emphasized in this course? primary concepts? secondary concepts? theory? application?

Marketing skills:

4. Teaching beliefs about what types of marketing skill should be taught in this course? quantitative? qualitative? technological? written communication? oral communication? research? leadership? selling? interpersonal? creative? management? problemsolving?

5. Teaching beliefs about what marketing skills should be emphasized in this course? primary skills? secondary skills?

Marketing Content Selection:

6. Teaching beliefs about who should select the marketing content for this course? instructor? academic department? students? textbook author? practitioners?

7. Teaching beliefs about what are acceptable sources from which to select marketing content for this course? academic textbooks? academic journals? trade publications? educator professional experience? internet?

Marketing Content Organization and Sequencing:

8. Teaching beliefs about how marketing content be organized for this course? by marketing function? bottoms-up? top-down? chronologically?

Marketing Content Mastery:

9. Teaching beliefs about what level of intellectual rigor (effort) is appropriate for this course? required cognitive effort? concept complexity? abstract-concrete concepts?

10. Teaching beliefs about what level of content mastery is appropriate for this course? concept recognition? recall? comprehension? application? synthesis?

\section{II.The Marketing Student}

Student Learning Styles:

II.Teaching beliefs about how marketing students in this course prefer to learn? direct experience? indirect experience? independent learning? cooperative learning? visually? problem-based learning?

Student Intellectual Capacity:

12. Teaching beliefs aboutg what intellectual abilities students bring to this course? quantitative skills? analytic skills? creative ability? artistic skills? problem-solving abilities?

Student Intellectual Motives/Attitudes:

13. Teaching beliefs about what personal learning goals and motives students bring to the course? intrinsic motivation: amount? subject-related? career-related? school-related? extrinsic motivation: amount? grades? parental pressure? social pressure? money?

Student Professional Competence:

14. Teaching belifs about what professional (marketing) competencies of students bring to this course? perquisite marketing knowledge? marketing skill? professional marketing experience?

Student Personal Development:

15. Teaching beliefs about what level of personal maturity students bring to the course? self-concept? confidence? emotional stability? dependability? integrity?

\section{III.The Marketing Educator}

Instructional Roles:

16. Teaching beliefs about what should be the dominant educator role(s) for this course? facilitator? expert? collaborator? boss? consultant? presenter? learner?

17. Teaching beliefs about what should be the dominant student role(s) for this course? learner? employee? team-leader/ member? educator? researcher? consultant? 
Table 2. (continued)

Instructional Delivery:

18. Teaching beliefs about what the appropriate instructional method(s) for this course? lecture? case method? independent study? individualized instruction? whole group instruction? cooperative learning? experiential learning?

19. Teaching beliefs about what instructional tone is appropriate for this course? formality? professionalism? structure? intimidating? challenging? clarity?

Instructional support:

20. Teaching beliefs about what instructional support is appropriate for this course? Type: instructor delivered? graduate student mentors? professional tutors? study groups? study aids (e.g., lecture outlines, study guides, past exams)? Amount: established office hours? additional study sessions? instructor assignment comments and feedback?

Learning Experience/Assignments:

21. Teaching beliefs about what student learning experiences are appropriate for the course? marketing cases? homework? student presentations? group projects? functional marketing tasks? marketing research? written reports? experiments? in-class? marketing simulations? client-based projects? field trips?

Educator Competence:

22. Teaching beliefs about what are the educator's instructional strengths and weaknesses? technological? professional marketing experience? academic research? interpersonal? presentation? problem solving? creative? quantitative?

Student Assessment - Learning:

23. Teaching beliefs about what type of student learning should be assessed in this course? marketing knowledge? marketing skills? attitudinal? problem-solving? innovative thinking? quantitative? career related? current marketing practice?

24. Teaching beliefs about what method(s) of student assessment (learning) should be used in this course? Exams: written? oral? essay? multiple choice? comprehensive? marketing cases? Who: faculty evaluations? peer-to-peer evaluations? student selfevaluations? third-party evaluations?

\section{IV.The Marketing Class}

Learning Climate:

25. Teaching beliefs about what type of social climate will best facilitate student learning? competitive? professional? cooperative? controlled? stressful? casual?

Group Interaction:

26. Teaching beliefs about what type \& amount of class interaction will best facilitate student learning? Type: student-to-student? student-instructor? small groups? whole group? student teams? structured? unstructured? personal? professional? Amount of class time: $25 \%$ ? $50 \%$ ? $75 \%$ ? $100 \%$ ?

Group Composition:

27. Teaching belief about what the appropriate class composition should be for the course? class size? diversity? business students? marketing students? non-business students? undergraduate students? graduate students?

Class Management:

28. Teaching beliefs about what classroom policies/procedures should be instituted in this course? attendance? participation? codes of conduct? testing? seating chart? instructor-designed? student-designed?

29. Teaching beliefs about what type of student reward system(s) should be instituted in this course? incentives for professional development? academic development? incentives for personal development? no rewards?

\section{V.The Marketing Classroom}

Physical classroom design:

30. Teaching beliefs about what types of classroom facilities are required for this course? Physical layout: seating? arrangement? learning centers? spacing? comfort? visual stimulations? acoustics? lighting? Instructional technology: white board? video? audio? computer? wireless?

3I. Teaching beliefs about what impact various physical (classroom) design elements have on the educator? Instructional motivation and performance:

32. Teaching beliefs about what impact the various physical (classroom) design elements have on students? student academic motivation and performance? social behavior? personal development? professional development? class participation? learning climate? 
behavior. Do teaching practices implemented by marketing educators support their espoused teaching philosophy? Or do serious instructional discrepancies exist within the educator's own teaching style? The process of systematically contemplating such questions can capture what we consider to be the spirit and essence of using a teaching-style audit approach and encourage valuable teaching reflection (Schon, 1983, 1987).

Belief-eliciting questions included in a teaching-style audit can encourage marketing educators to conduct systematic comparisons between their instructional beliefs and their behaviors. By assessing this internal consistency, on the basis of their responses to sets of questions, educators can readily identify areas of teaching-style congruence and incongruence. For example, if a respondent holds the strong belief that the students play a key role as educators (i.e., delivering important marketing content to other students), a congruent behavior would be to devote a large percentage of instructional time to the delivery of marketing content through student-to-student interactions (e.g., small student group discussions, cooperative learning opportunities). Alternatively, the failure to provide such student-to-student interactions would reveal an incongruent teaching style and suggest the need to reexamine the teaching behaviors.

Analyzing an educator's audit responses also helps reveal areas of teaching-style congruence that promote student learning. Reflective teaching practices require educators to consider areas of teaching-style congruence carefully and thereby identify opportunities to adjust their teaching behaviors and strategies to strengthen these teaching-style congruencies further. For example, if the use of experiential learning activities is congruent with a teacher's instructional beliefs, the question becomes how to provide more or better experiential learning opportunities to students. An educator's teaching style will likely contain varying levels of congruence over the course of his or her professional life. As such, marketing educators will always have the opportunity to increase the amount of congruence in their teaching style by adding additional instructional activities that align with their instructional belief system.

However, all teaching-style congruence may not be healthy. Healthy congruence requires a proven, time-tested set of teaching beliefs or philosophies; congruent but unhealthy teaching styles rely on faulty or unsound instructional beliefs. Moreover, unhealthy congruent teaching styles can be extremely detrimental to effective classroom instruction. Marketing educators need to reflect thoughtfully on all areas of congruence identified by the teaching-style audit. Areas of unhealthy congruence also may be revealed through the evidence gleaned from other traditional indicators of instructional effectiveness, such as student evaluations, student exam scores, academic performance, and peer teaching evaluations.

Finally, a teaching-style audit is likely to reveal areas of incongruence within the teaching style, which should prompt thoughtful reflection on the underlying cause(s). Do the educator's areas of incongruence result from a poorly developed instructional belief system? Has the marketing educator simply failed to design and implement course instruction that consistently supports his or her instructional beliefs? Have uncontrollable, external factors led the educator to compromise the integrity of his or her personal instructional philosophy? One educator might believe that students learn most effectively through direct experience but offer few hands-on learning opportunities because of large class sizes or a classroom design that prohibits such activities. Identifying the underlying causes of teaching-style incongruence enables educators to devise pedagogical responses that may minimize or eliminate that incongruence from their teaching style. Pedagogical responses to style incongruence thus require educators to either revise their teaching beliefs or change their instructional behavior.

Changing instructional beliefs can be a difficult and slow process. However, the process can be the source of serious professional growth that results in dramatic improvements in marketing instruction. For example, consider a marketing educator who believes marketing cases offer valuable student learning experiences yet rarely assigns or uses them. In this example, the beliefs and behavior of the educator are clearly incongruent. As the educator reflects on this paradox, he or she should begin to question whether marketing cases really are valuable as learning experiences. If cases are so valuable, why not use more of them? Could it be that this instructor really does not believe cases are particularly beneficial to marketing students? On further reflection, the educator may begin to consider the instructional drawbacks of the case method: They consume a substantial amount of class time, tend to focus on a narrow set of marketing issues (content), and prompt in-class case discussions that can revolve around the insights of a limited number of students. In this example, rather than just incorporating more marketing cases into course instruction, the educator may elect to revise his or her instructional beliefs, which will increase teaching-style congruence.

Improved style congruence also can be achieved by changing instructional behaviors to align with the instructional belief system. This shift requires marketing educators to reflect carefully on their instructional practices to ensure they are consistent with their beliefs about the teachinglearning exchange. Continuing with the preceding example, the educator might elect to increase teaching-style congruence by adjusting his or her teaching behavior and incorporate more marketing cases into classroom instruction. 


\section{Instrument Strengths and Weaknesses}

Throughout this discussion, we have proposed the use of an audit instrument to enable marketing instructors to self-examine their instructional beliefs and behaviors. But a teaching-style audit, like any assessment device, has both strengths and weaknesses. For example, a teaching-style audit can be a selfadministered reflective experience. Self-administration allows marketing educators to think openly and honestly about their instructional performance, without the fear of professional embarrassment that may accompany other forms of reflection (Osterman \& Kottkamp, 1993). A teaching-style audit also might be used effectively in conjunction with other traditional reflective teaching methods (see Table 1). The teaching-style audit might be employed to uncover personal teaching beliefs, and then videotaping or peer-observation used to provide information about educator classroom teaching behaviors. Furthermore, a teaching-style audit can span several reflective sessions and address each major element of the marketing teaching-learning exchange separately. For example, the audit instrument in Table 2 consists of five distinct sections that might be assessed independently over several assessment sessions. This approach could be beneficial for educators who need more time to adequately address each of the pedagogical issues raised by the audit.

Teaching-style audits can also be adapted to suit the needs of different groups of marketing educators. For example, doctoral programs might employ the instrument to accelerate the professional development of its doctoral students (i.e., promote the development of an effective teaching philosophy); educational administrators might require its completion to assess faculty instruction. Furthermore, a teaching-style audit framework might provide an insightful discussion format for a faculty retreat or workshop.

We also recognize that a teaching-style audit contains pedagogical limitations, though most of them can be overcome by augmenting the audit with a few simple, complementary procedures. The marketing teaching-learning framework we propose, though comprehensive, still represents an oversimplification of the complex activity of teaching. Therefore, the instructional issues raised by any teaching-style audit based on this framework must be viewed as an initial, rather than definitive, list of points for pedagogical reflection. The teaching-style audit should be viewed as a living instrument that can evolve and grow (i.e., by adding new and different reflective prompts) as the educator develops as a teaching professional. Furthermore, the proposed marketing teaching-learning exchange represents one possible unifying framework; other conceptual frameworks also might be developed to guide the reflective process. Finally, self-assessment approaches to reflective practices have limitations; for example, they assume marketing educators can, and will, be objective and honest with themselves about their own teaching beliefs and behaviors.

In summary, a teaching-style audit has both strengths and weaknesses as an approach to reflective teaching practice. We therefore suggest that marketing educators use a teaching-style audit approach in concert with other traditional procedures for assessing teaching effectiveness (e.g., student teaching evaluations, peer evaluations, student performance). For interested readers we have included in a brief summary of our personal thoughts and experiences using the teaching-style audit in Appendix B.

\section{Conclusion}

Growing as an educator takes hard work and commitment. Educators must regularly engage in thoughtful self-examinations of their instructional beliefs and behaviors, because real growth comes only when educators carefully question and challenge their instructional beliefs and behaviors. This process can be conducted in a more or less systematic manner. It also can be a daunting and at times unwieldy task, because it must account for the vast complexity of the teaching-learning exchange. In this article, we propose a framework for systematically examining teaching style, suggest the use of a teaching-style audit to assist marketing educators in their selfexaminations of their instructional beliefs and behaviors, and provide an illustrative example of one such possibility. Our hope is that this discussion will encourage further improvements to current instructional practices in marketing education. 


\section{Appendix A}

\section{Teaching-Style Audit: An Illustrative Example ${ }^{a}$}

\begin{tabular}{llll}
\hline Personal Beliefs & Corresponding Teaching Behaviors & $\mathrm{C} / \mathrm{l}$ & Points of Reflection \\
\hline
\end{tabular}

V. The Marketing Classroom

30. Beliefs about classroom design and this course.

- I believe a current, up-to-date, stateof-the art classroom can motivate students to want to come to class and get excited about course material.

- I believe the appearance of such facilities is also important. Notebook papers, food wrappers, or student newspapers left scattered in a classroom, stained carpets, broken chairs, or peeling paint found in a classroom make for an unpleasant environment and may distract students from learning as well as they could or should.

- I think the instructional equipment present in the physical environment can help facilitate learning.

- I believe additional materials should be present in the classroom to expose students to, and encourage thinking about, a variety of marketing issues. Such materials might include reading materials (e.g., textbooks, The Wall Street Journal, BusinessWeek).

- I believe wall colors, flooring materials, artwork, temperature, and sounds in classrooms can be used to create a stimulating learning environment.
- I regularly inspect available classrooms and try to schedule my courses in the newer buildings and recently refurbished classrooms on campus.

- Before each class, I arrive early to ensure the equipment is in working order and all chairs are in place.

- Prior to and immediately after class, I pick up trash left behind and arrange the seating in an orderly fashion.

- I sometimes ask students who bring food or newspapers to the classroom to clean up themselves and to leave the classroom cleaner than they found it. (Often, however, I just clean it myself rather than ask.)

- I regularly request that my classes are scheduled in rooms with appropriate, state-of-the art equipment installed to allow the presentation and review of multiple types of media.

- I structure my lectures around using as much equipment as I feel comfortable using, such as PowerPoint presentations via overhead projection systems and video clips from movies displayed to illustrate course concepts.

- I do not bring in such materials to the classroom, even though I do have (or could easily acquire) access to them. (I see this as too much of a bother for me. I would have to push a cart or cart around a large box of materials every time I went to class.)

- With the exception of playing music CDs before my class starts, I do very little to create a more stimulating environment in the classroom. (I generally feel as if there is nothing I can do and that classroom design is not my responsibility.)
C Does the physical environment really serve to motivate students? Or to improve student attendance? What about the possible impact on student participation?

C Besides diverting student attention, how does cleanliness impact student learning? Does cleanliness serve as an environmental stressor? Or as a mood-altering agent? What messages are communicated implicitly to students via environmental cleanliness?

C - What precisely is the impact of instructional technology on student learning, student attendance, or class participation? My beliefs here are not particularly well founded. Yet I regularly attend classes at my university's Center for Teaching and Learning to stay abreast of recent advances that might be incorporated into the classroom experience.

I - How might I reconcile this instructional inconsistency? Possibly assign students the task of bringing such materials to class? Could computer technology be used to import virtual magazines and reading materials (e.g., Web sites)?

I - Apart from the use of music, what other opportunities are there to create a stimulating learning environment? Possibly adding visual, tactile, or auditory stimulation?

C - How is my instructional behavior influenced by the classroom environment? My personal motivation? Instructional delivery? Interaction with the students? 


\section{Appendix A (continued)}

\begin{tabular}{|c|c|c|c|}
\hline Personal Beliefs & Corresponding Teaching Behaviors & $\mathrm{C} / \mathrm{I}$ & Points of Reflection \\
\hline $\begin{array}{l}\text { - I believe out-of-date, poorly } \\
\text { maintained classroom and other } \\
\text { educational facilities can discourage } \\
\text { or inhibit my performance. }\end{array}$ & $\begin{array}{l}\text { - I often complain to fellow faculty about } \\
\text { poor classrooms and/or equipment but } \\
\text { generally do not do much beyond that. }\end{array}$ & 1 & $\begin{array}{l}\text { - How might I reduce the teaching } \\
\text { incongruence here? Is it possible to } \\
\text { minimize the environmental impact on } \\
\text { my instructional performance? Complain } \\
\text { more effectively? Should I reduce the } \\
\text { educational importance I place on such } \\
\text { issues? Minimize frustration? }\end{array}$ \\
\hline $\begin{array}{l}\text { I think poorly designed classrooms } \\
\text { (i.e., stationary seats, tiered levels, } \\
\text { small student desks, tile floors) in a } \\
\text { classroom suggest a lower quality } \\
\text { educational experience and make } \\
\text { me feel as though I am teaching } \\
\text { in an inferior room (and, perhaps, } \\
\text { business school). }\end{array}$ & $\begin{array}{l}\text { - I don't do anything about poorly } \\
\text { designed classrooms, other than ask to } \\
\text { have my classes not scheduled in these } \\
\text { rooms. }\end{array}$ & I & $\begin{array}{l}\text { Although institutional constraints } \\
\text { often prevent me from addressing } \\
\text { this incongruence, it does suggest } \\
\text { the need to be more aware of the } \\
\text { messages communicated to me by the } \\
\text { physical environment. What messages } \\
\text { can or should be sent via the physical } \\
\text { environment? }\end{array}$ \\
\hline
\end{tabular}

32. Beliefs about classroom design and student learning.

- I believe important aspects of any class are in-class activities, small group discussion, and active learning exercises. I believe the physical layout and arrangement of furniture in the classroom can influence the quality and nature of these interactions. (In particular, I believe that rooms with movable chairs and tables make it much easier to conduct small group activities than tiered classrooms with immovable seats.)

- I believe the design of the classroom affects the ability of the instructor to develop rapport with students in a class.
- Regardless of the physical layout and design of the classroom I am assigned, I force students to form groups and engage in group activities. (I just assume students will adapt, and I am not really concerned if they like it or not.) In tiered classrooms with immovable seats, I am aware that such a requirement makes it difficult for students to interact with one another.

- When the classroom (for 40-60 students) has individual seats (desks) arranged in rows, I sometimes (time permitting) move seats to make a wider central aisle that allows me to easily move from the front of the room to the back-allowing me to better connect with more students.
1 - Although my behavior is congruent with my beliefs, it is also generally independent of the layout of the classroom. What loss in student learning, if any, occurs because of this instructional behavior? What is the impact on group interaction (e.g., amount, duration, group size)? Are students really that flexible?

C Are there other environmental strategies that I can employ to increase and improve faculty — student interaction? Are there teaching strategies that will allow me to deliver a more personal learning experience?

Note: $\mathrm{C}=$ teaching-style congruence; $\mathrm{I}=$ teaching-style incongruence

a. To illustrate how an instructor might use this teaching-style audit, the second author provides a self-reflection on one of the dimensions of the teaching learning exchange discussed in the article - the physical environment. We limit the focus here to just one dimension (the marketing classroom) as a means to illustrate more extensively an assessment of beliefs, behaviors, and congruence (or incongruence) in a subset of issues of this dimension.

\section{Appendix B}

\section{Author Reflections on the Teaching-Style Audit}

We have spent considerable time reflecting on the many philosophical and instructional issues raised by the TSA. Those pedagogical reflections have resulted in a variety of philosophical changes to our instructional beliefs, as well as changes to our classroom instruction. In this section, each of us provides a sampling of some of our personal reflections on the TSA and how it has affected our teaching philosophy and style.

\section{Reflections:Author I}

In addition to prompting specific changes to my classroom instruction (described in the next paragraph), the TSA has significantly broadened the scope of my pedagogical reflection-pushing me to reflect on instructional issues that I had previously overlooked or ignored. Admittedly, prior to the development of the TSA, I gave embarrassingly little consideration to my pedagogical beliefs regarding issues such as content selection and prioritization, student learning styles, instructional roles (of both educator and student), the use of affective domains of learning, or the use of nontraditional methods of student assessment (e.g., third party evaluations). Rather, prior to the development of the TSA, the majority of my pedagogical reflection was narrowly centered on "instructional delivery" and "classroom management" issues. 


\section{Appendix B (continued)}

In response to the TSA, I have modified my teaching style to be less reliant on author-selected and prioritized (textbook-bound) marketing content. I am now much more inclined to supplement marketing textbook content with practitioner-authored readings or marketing-related content authored by thought leaders from a various fields of inquiry. I am also much more willing to devote valuable instructional time to "affective" marketing content, addressing the many misconceptions and attitudinal inaccuracies students hold about marketing theory and practice.

Furthermore, many of my courses now contain client-based projects (practitioner-judged) designed to bring a level of "realism" to the learning experience that is difficult to do with traditional in-classroom instruction. These client-based projects also provide students with independent, third party assessments of their performance. As part of my client-based projects, I now regularly include a professional development component. The professional development component includes a formal "hiring" process whereby I (as the instructor) hire students to serve as marketing team leaders. Each student marketing team leader is then charged with the responsibility to conduct formal interviews with fellow classmates to select or hire additional marketing team members. Prior to the development of the TSA, inclusion of "professional development" content was not something that I readily embraced as a learning priority, but now see its instructional value. These instructional changes have been a direct result of some new thinking generated by the development of the TSA.

It is important to note that use of a TSA can produce some anxiety for its users by raising instructional issues that are difficult to resolve. For instance, I am still wrestling with how much instructional support (e.g., instructor-assistance/modeling, instructor-provided study aids) to provide students, and how or whether it is prudent to accommodate differences in student learning styles. Many of these unresolved issues have prompted me to seek out the advice of my colleagues, thus generating valuable pedagogical discussions that would not have ordinarily occurred.Additionally, I have found myself much more willing to enter into informal pedagogical discussions with my students. For instance, I am now much more likely to pretest many of my pedagogical beliefs by soliciting student reactions to various teaching practices prior to their implementation - especially pedagogical beliefs that may be unpopular with students (e.g., not offering online lecture notes, providing minimal information on PowerPoint slides, forced student class participation). Interestingly, these informal pedagogical discussions with students and faculty have been the most surprising, albeit pleasant, effect that the TSA has had on my personal development as an educator.

Reflections:Author 2

In the appendix, I have demonstrated how I used the TSA to assess and reflect on my teaching when it comes to "the marketing classroom." Completing the marketing classroom section of the TSA reaffirmed my strong beliefs that the physical environment in which a course is delivered can have quite an influence on students and their experience in a course. Perhaps the most valuable takeaways for me from completing the TSA were the issues and questions that surfaced (and are noted in the "Points of Reflection" column in the appendix). In some cases, I found that I behave in a manner that is consistent with my beliefs, but in other cases I do not. I did not spend much time dwelling on those issues where my behavior and beliefs are congruent, but I did find it disturbing when there were incongruencies. And, these issues seemed to resurface occasionally long after I had finished completing the TSA.

I also found that working through the section of the TSA that appears in the appendix and writing down my beliefs and behaviors caused me to feel somewhat guilty about not doing more to act on my beliefs. This feeling led me to go out of my way to volunteer to be the "guinea pig" for testing out the room and equipment in a completely refurbished classroom on campus at the end of the previous school year. I generally do not volunteer for such endeavors, but I thought that this was one action I could take to make a contribution that was consistent with my beliefs. And, I thought it would be helpful to our IT staff to help them identify any "bugs" that needed to be worked out before the classroom would be used for summer offerings. (I also thought my students would appreciate the upgrade from the [very poor] classroom we were meeting in.) As it turned out, the construction schedule ended up going slightly beyond the end of the school year, and my classes were not able to test out the equipment. But, at least I volunteered!

This semester I was placed into this new classroom (which is now used to showcase the university and has been the location of the filming of a commercial for the university). I still believe in the importance of the classroom, but my experience thus far suggests that perhaps students do not share my perspective. Although students may appreciate the state-of-the-art classroom with new furniture, improved lighting, and great viewing angles, not one student has ever mentioned the classroom within, or outside of, the course. I have observed that having such a wonderful classroom does not appear to have had any impact on student attendance (i.e., overall attendance is at the same level as in previous courses) or on performance in the course (i.e., students are not doing any better than in previous courses). Thinking of the TSA, I wonder: Do I need to revisit my beliefs about the impact of the environment on students in my courses?

Note:TSA = teaching-style audit.

\section{Declaration of Conflicting Interests}

The authors declared no potential conflicts of interest with respect to the authorship and/or publication of this article.

\section{Funding}

The authors received no financial support for the research and/or authorship of this article.

\section{References}

Adelson, J. (1961). The teacher as model. The American Scholar, 30, 383-406.

Armstrong, D. G. (1989). Developing and documenting the curriculum. Needham Heights, MA: Allyn \& Bacon.

Axelrod, J. (1970). Teaching styles in the humanities. In W. J. Morris (Ed.), Effective college teaching: The quest for 
relevance (pp. 38-55). Washington, DC: American Council on Education.

Axelrod, J. (1973). The university teacher as artist. San Francisco: Jossey-Bass.

Berry, L. L., Conant, J. S., \& Parasuraman, A. (1991). A framework for conducting a services marketing audit. Journal of the Academy of Marketing Science, 19, 255-268.

Conti, G. J. (1985). Assessing teaching style in adult education: How and why? Lifelong Learning, 8, 7-11.

Conti, G. J. (1990). Identifying your teaching style. In M. W. Galbraith (Ed.), Adult learning methods: A guide for effective instruction (pp. 79-96). Malabar, FL: Krieger.

Cross, K. P. (1979). Adult learners: Characteristics, needs, and interests. In R. E. Peterson \& Associates (Eds.), Lifelong learning in America: An overview of current practices (pp. 75-141). San Francisco: Jossey-Bass.

Dewey, J. (1933). How we think: A restatement of the relation of reflective thinking to the educative process. Boston: D. C. Heath.

Fisher, B. B., \& Fisher, L. (1979). Styles in teaching and learning. Educational Leadership, 36, 245-254.

Freiberg, H. J., \& Driscoll, A. (2000). Universal teaching strategies (3d ed.). Needham, MA: Allyn \& Bacon.

Hall, S. (1997). Forms of reflective teaching practice in higher education. In R. Pospisil \& L. Wilcoxson (Eds.), Learning through teaching (pp. 124-131; Proceedings of the 6th Annual Teaching Learning Forum). Perth, Australia: Murdoch University.

Heck, S. F., \& Williams, C. R. (1984). The complex roles of the teacher: An ecological perspective. New York: Teachers College Press.

Heimlich, J. E., \& Norland, E. (2002). Teaching style: Where are we now? New Directions for Adult and Continuing Education, 93, 17-25.

Henke, J. W., Jr., Locander, W. B., Mentzer, J. T., \& Nastas, G., III. (1988). Teaching techniques for the new marketing instructor: Bring the business world into the classroom. Journal of Marketing Education, 10, 1-10.

Humphreys, K., \& Ziva, S. (2000). Learning how to fish: Issues for teachers engaged in self-evaluation and reflective enquiry in school. Research in Education, 64, 78-90.

Kotler, P., Gregor, W. T., \& Rogers, W. H., III. (1977). The marketing audit comes of age. Sloan Management Review, 18, 25-43.

Leung, K. K., Lue, B. H., \& Lee, M. B. (2003). Development of a teaching style inventory for tutor evaluation in problem-solving. Medical Education, 37, 410-416.

Mann, R. (1970). The college classroom: Conflict, change, and learning. New York: Wiley.
McNeil, J. D. (1996). Curriculum: A comprehensive introduction (5th ed.). New York: HarperCollins.

Mokwa, M. P. (1986). The strategic marketing audit: An adoption/ utilization perspective. Journal of Business Strategy, 6, 88-95.

Nicholls, A., \& Nicholls, H. S. (1978). Developing a curriculum: A practical guide for teachers at primary, secondary and tertiary levels. Boston: HarperCollins.

Oliva, P. F. (1982). Developing the curriculum. Boston: Little, Brown.

Oliva, P. F. (2005). Developing the curriculum (6th ed.). Boston: Pearson Education.

Osterman, K. F. (1990). Reflective practice: A new agenda for education. Education and Urban Society, 22, 133-152.

Osterman, K. F., \& Kottkamp, R. B. (1993). Reflective practice for educators: Improving schooling through professional development. Newbury Park, CA: Corwin Press.

Payne, A. F. (1988). Developing a marketing-oriented organization. Business Horizons, 31, 46-53.

Posner, G. J., \& Rudnitsky, A. N. (2001). Course design: A guide to curriculum development for teachers (6th ed.). New York: Addison Wesley Longman.

Ramsden, P. (1992). Learning to teach in higher education. London: Routledge.

Richey, R. C. (1986). The theoretical and conceptual bases of instructional design. New York: Kogan Page.

Roach, S. S., Johnston, M. W., \& Hair, J. F., Jr. (1993). An exploratory examination of teaching styles currently employed in marketing education: Developing a typology and its implications for marketing students. Journal of Marketing Education, $15,32-38$.

Robinson, F. G., Ross, J. A., \& White, F. (1985). Curriculum development for effective instruction. Toronto, Ontario, Canada: Ontario Institute for Studies in Education Press.

Saroyan, A., \& Snell, L. S. (1997). Variations in lecturing styles. Higher Education, 33, 85-104.

Schon, D. A. (1983). The reflective practitioner. New York: Basic Books.

Schon, D. A. (1987). Educating the reflective practitioner: Toward a new design for teaching and learning in the professions. San Francisco: Jossey-Bass.

Shuchman, A. (1959). The marketing audit: Its nature, purposes, and problems. In A. Newgarden \& E. R. Bailey (Eds.), Analysis and improving marketing performance: Marketing audits in theory and practice (pp. 11-19). New York: American Management Association.

Wiles, J., \& Bondi, J. (2002). Curriculum development: A guide to practice (6th ed.). Upper Saddle River, NJ: Merrill Prentice Hall. 